\title{
Lubricating Aspects of Automotive Fuels
}

\author{
Evripidis Lois and Panagiotis Arkoudeas
}

Additional information is available at the end of the chapter

http://dx.doi.org/10.5772/48552

\section{Introduction}

Back in the 1960s, the term "lubricity" was defined by Appeldorn and Dukek as: "If two liquids have the same viscosity, and one gives lower friction, wear or scuffing, it is said to have better lubricity". It should be noted, however, that this definition was not strictly applied and many researchers carried out lubricity experiments on fuels based on their own understanding of the concept. The lubricating ability of fuels, because of their very low viscosity, depends mostly on their boundary film-forming properties. Some moving parts of diesel fuel pumps and injectors are protected from wear by the fuel. To avoid excessive wear, the fuel must have some minimum level of lubricity. Lubricity is the ability to reduce friction between solid surfaces in relative motion. The lubrication mechanism is a combination of hydrodynamic lubrication and boundary lubrication. In hydrodynamic lubrication, a layer of liquid prevents contact between the opposing metal surfaces. For diesel fuel pumps and injectors, the liquid is the fuel itself and viscosity is not the key fuel property as one could profoundly expect. The history of fuel lubricity is associated with problems in engine performance as liquid-hydrocarbon based fuels must possess a minimum of lubricating ability to be able to protect high-pressure injection pumps and related fuel supply equipment from wear. The topic of gasoline lubricity has recently become more urgent with the introduction of direct-injection gasoline engines, which will necessitate high-pressure gasoline injection pumps, a development that is most likely to place considerably more emphasis on the lubricating ability of gasoline, accelerating wear especially in rotary distributor fuel pumps. According to pump manufacturers this loss of lubricity may be the difference between fuels from a controlled laboratory environment and a cost-conscious production environment. [1-7].

In the last decades, the demand for both gasoline and automotive diesel fuel has increased rapidly and strongly. In the early 1990s, world gasoline production rose to about 800 billion litres, about half of which was consumed in the United States. The world demand for gasoline is estimated to be an average 20 million barrels a day. The United States is the largest consumer with an average consumption of around 8.9 million barrels a day in 2008, 
accounting for over $40 \%$ of global consumption. This was over 9 million barrels a day in 2007. However, the production of gasoline in any country depends on the type of economy it follows. For example, while US have adopted a gasoline based economy, India is largely a diesel based economy, leading to more production and consumption of gasoline in US and High-Speed Diesel (HSD) in India. Moreover, the light sweet crude oil used by US, yields more gasoline. So, there are considerable differences in the relative demand for gasoline and diesel fuels from region to region. The refinery industry has met these challenges by improving efficiency of crude oil utilisation, increasing the depth of crude oil processing and reducing product losses as well as adjusting refining processes to maximise production of either gasoline or diesel fuel [1-4, 8].

Fuel composition is a key factor in determining the lubricity of fuels, since it depends not only on the crude oil the fuel is prepared from, but also on the refinery process, finishing process, and blending method. The gradual increase in severity of refinement in recent years to meet tightening environmental regulations has simultaneously reduced the concentration of many potential lubricity agents and thus made fuel lubricity poorer. Gasoline is the lightest liquid fraction of petroleum, boiling between about $30^{\circ} \mathrm{C}$ and $200^{\circ} \mathrm{C}$, i.e. containing mainly $\mathrm{C} 5$ to $\mathrm{C} 12$ hydrocarbons. It is reasonable to infer that the inherent lubricity of gasoline will be poorer than that of aviation fuel and diesel fuel due to the lighter distillation cut, in which natural antiwear impurity concentration will be lower. Fortunately and till now, the lubricity requirements of gasoline are generally much lower than for diesel since gasoline fuel injection systems inject fuel upstream of the inlet valves and thus operate at much lower pressures than diesel fuel pumps.

In 1990s, the amount of sulphur, nitrogen and aromatics in diesel fuels was reduced by severe hydrotreating to minimize SOx emissions from diesel powered vehicles. The use of low sulphur diesel fuels led to numerous pump failures. To combat the loss of this lubrication, packages of additives that increase lubricity could be blended with the fuel prior to distribution [9]. The lubricity characteristics of diesel fuel are similar to aviation turbine fuels, up to the middle of the 1980s, but the lubricity of diesel fuels was not considered a significant factor that could lead to serious problems and little work concerning diesel lubricity had been carried out. There was not widely accepted test method existed to determine the lubricity of diesel fuels. In the 1990s, Sweden and United States introduced low sulphur, low aromatic diesel fuels and this was followed by other countries, including Canada, Switzerland, Austria, and Germany. Soon after the introduction of these environmental diesel fuels in the Scandinavian and Californian markets in the early 1990s, a number of injector equipment failures were reported from all manufacturers. These failures took place in passenger cars working with Bosch rotary pumps after only 3000 to 10,000 km. In Europe and the USA, such fuels have been shown to reduce the life of distributor type pumps by up to $95 \%$. Field trials and pump rig durability testing of both Swedish Class 1 and 2 showed that their inherent lubricity was unacceptable [9-15]. Diesel fuel work has revealed that humidity, which reflects environmental water vapour pressure, can have an important influence on the friction and wear, although this was not taken into account in test work until recently [1-7, 9-15]. It is possible to eliminate, at least to a large extent, the influence of humidity on test repeatability of friction, wear, and film formation by carefully controlling humidity in a relative narrow range 
[1-7]. A survey of low sulphur diesel fuels (sulphur content ranged from 1 to $498 \mathrm{ppm}$ ) has showed that in spite of high refinement most low sulphur diesels still contain considerable residual polyaromatics ( 0.3 to $2.2 \% \mathrm{wt}$ ) and diaromatics (2 to $11 \% \mathrm{wt}$.). A detailed analysis of data has suggested that even in low sulphur diesel fuels, polyaromatics may still play a more important role than diaromatics in determining diesel lubricity.

Gasoline lubricity is a complex phenomenon, involving many complicated and interconnecting factors, such as the presence of water, concentration of sulphur, nitrogen, oxygenates, diolefins, diaromatics, the effect of viscosity and the synergistic effect of different wear mechanisms. The lubricity mechanism of gasoline is quite different from that of diesel fuels that leads to severe adhesive wear. With low-sulphur fuels, adhesive wear is observed instead of corrosive and mild oxidative wear, and deposits build up on top land [1-4]. Metallurgy and mechanical properties of test specimens used to study wear have important effects on the lubricating mechanisms of fuels. When the hardness of the lower specimen in an HFRR test is not enough to support the generated oxide films formed by the reaction between surfaces and dissolved oxygen and the adsorption films formed on top of the oxide films by gasoline polar impurities, severe adhesion and metal transfer occur [1-7, 9-15]. The wear behaviour of some gasolines was found to be sensitive to the time of exposure to air, in that the wear values obtained fell slightly after the fuel container had been opened several times. This may be due to the oxidation of gasoline components. Gasolines containing olefins, and dienes, in particular, which have very poor oxidation stability [1-7]. However, polyaromatics in gasolines are absent due to the lower boiling range and only a few thousandths by volume of diaromatics, i.e. naphthalenes are present. More than $99 \%$ of aromatics in gasoline are monoaromatic, i.e. benzene, toluene and xylenes [1-7, 16-19].

In this chapter, the effect of various compositional and physicochemical characteristics of automotive fuels will be examined, with respect to their lubrication mechanisms. Additionally, tribological aspects (e.g. wear scar analysis, Scan Electron microscopy, etc) of automotive fuels and their mixtures with biofuels or/and bio-additives like essential oils will be presented and discussed.

\section{Diesel fuel lubricity and addition of essential oils}

For diesel fuel, the 1980s was an important transition period from high lubricity to moderate lubricity due to the increase of severity of refinement. Hydrotreating processes were widely used and these doubtless caused a great reduction of natural lubricity agents in diesel fuels. However, unlike aviation kerosene, no major lubricity problems were encountered in diesel fuels until the late 1980s. This may be because:

a. Diesel fuel has a higher boiling temperature range than kerosene and thus contains a larger proportion of naturally-occurring lubricity agents.

b. The severity of the refinement used in the production of early- and middle-1980s diesel fuels was moderate and this allowed enough naturally-occurring lubricity agent to survive during refining and maintain adequate lubricity.

c. In general, diesel fuels have higher viscosity, which is beneficial to film formation. 
Recent concerns over the environmental impact of diesel powered equipment have driven various countries to legislate reductions in vehicle exhaust emission levels and changes to diesel fuel quality. These reductions in exhaust emissions have caused changes in engine design such as increased fuel injection pressure and control of the fuel injection. Hardware changes tend to require improved diesel fuel lubricity to avoid excessive wear of the fuel injection system [20-22].

Past studies showed that diesel lubricity is largely provided by trace levels of naturally occurring polar compounds which form a protective layer on the metal surface. Typical sulfur compounds do not confer this wear protection themselves; rather it is the heterocyclic aromatics and nitrogen and oxygen compounds that are the most important [23-25]. A complex mixture of polar compounds is found in diesel, and some are more active than others. The process of hydrotreating to reduce sulfur levels also destroys some of this natural lubricant. Other refinery processes also influence the concentration of the lubricity agents in the final fuel blend [26]. Lubricity additives have been developed to compensate for the deterioration in natural lubricity observed in low sulfur diesels. A moderate dosage of chemically suitable additive is beneficial in most cases, but if the dosage is too high, some common diesel-fuel additives can cause fuel injector deposits, water separation problems, or premature filter plugging. These problems are not always identified in the standard fuel specification tests, and result in field problems [27-29].

In this chapter, results are presented on the lubricating properties of low sulfur diesel fuels additized with ten different essential oils. Data were generated to identify the minimum concentration of the above oxygen containing compounds, which provide lubricity improvement down to the $460 \mu \mathrm{m}$ wear scar diameter (WSD) level. The value of $460 \mu \mathrm{m}$ was proposed by the European Committee for standardization (CEN) in February 1997, and generally adopted by the industry, as the minimum requirement for an acceptable field performance [30].

Oxygen containing compounds such as fatty acids are superior friction reducing agents. These compounds adsorb or react on rubbing surfaces to reduce adhesion between contacting asperities and limit friction, wear and seizure [31-34]. Wei and Spikes considered that the significant wear reduction was produced by oxygen compounds with phenolic-type or carboxylic acid groups and occurred at a concentration of just a few parts per million [35]. Essential oils contain omega-3 and omega-6 fatty acids like a-Linolenic acid (18:3), Linoleic acid (18:2), eicosapentaenoic acid (20:5), docosahexaenoic acid (22:6), gamma-linolenic acid (18:3), dihomo-gamma-linolenic acid (20:3) and arachidonic acid (20:4). They also contain ethers, esters and terpenes [36].

Although the lubricating efficiency of fatty acids and their derivatives has been closely examined, the impact of adding other oxygenates such as essential oils has not been examined in detail. On the other hand, the addition of these oxygenates to diesel fuel has been proposed as a method to help complete the oxidation of carbonaceous particulate matter and associated hydrocarbons, thereby reducing particulate matter PM emissions [37-39]. 


\subsection{Experimental procedure focused on enhancing diesel lubricity by addition essential oils}

To assess the impact of the selected oxygen components on the lubrication properties of low sulfur automotive diesel, two fuels (A1 and A2) that comprised distillates of the hydrodesulfurization process were obtained by a Greek refinery and were used for all the tribological experiments as base fuels. The fuel properties are presented in Table 1, along with the standard methods that were used for their determination.

\begin{tabular}{cccc}
\hline Fuel code & A1 & A2 & Test method \\
\hline Density $\left(\mathrm{kg} / \mathrm{m}^{3}, 15^{\circ} \mathrm{C}\right)$ & 0.832 & 0.838 & ISO 12185 \\
Viscosity $\left(\mathrm{cSt}, 40^{\circ} \mathrm{C}\right)$ & 2.86 & 2.78 & ISO 3104 \\
CFPP $\left({ }^{\circ} \mathrm{C}\right)$ & -8 & -11 & ISO 116 \\
Flash point $\left({ }^{\circ} \mathrm{C}\right)$ & 61 & 88 & ISO 2719 \\
Cetane number & 57.9 & 52.2 & ISO 5165 \\
Cetane Index & 55.8 & 49.0 & ASTM D 4737 \\
Sulphur $(\mathrm{ppm})$ & 31 & 51 & ASTM D 5453 \\
Nitrogen $(\mathrm{ppm})$ & 13 & 26 & ASTM D 5762 \\
Water $(\mathrm{ppm})$ & 117 & 154 & ISO 12937 \\
Total Acid Number $(\mathrm{mg} \mathrm{KOH} / \mathrm{g})$ & 0.12 & 0.15 & ISO 7537 \\
Refractive Index & 1.4595 & 1.4745 & ISO 5661 \\
Conductivity $\left(\mathrm{pS} / \mathrm{m}, 25{ }^{\circ} \mathrm{C}\right)$ & 48 & 299 & ISO 6297 \\
Calorific value $(\mathrm{Kcal} / \mathrm{kg})$ & 10120 & 9953 & ASTM D-240 \\
Residue $(\% \mathrm{~m} / \mathrm{m})$ & 1.32 & 0.92 & ISO 3405 \\
Mono-aromatics $(\% \mathrm{v} / \mathrm{v})$ & 22.3 & 23.5 & ASTM D-6591 \\
Di-aromatics $(\% \mathrm{v} / \mathrm{v})$ & 3.8 & 3.7 & ASTM D-6591 \\
Poly-aromatics $(\% \mathrm{v} / \mathrm{v})$ & 0.10 & 0.16 & ASTM D-6591 \\
Distillation $\left({ }^{\circ} \mathrm{C}\right)$ & & & \\
IBP & 168 & 168 & ISO 3405 \\
$10 \%$ & 213 & 198 & ISO 3405 \\
$50 \%$ & 278 & 3268 & ISO 3405 \\
$90 \%$ & 334 & 349 & ISO 3405 \\
FBP & 358 & ISO 3405 & ISO 12156 \\
\hline Lubricity $(\mu \mathrm{m}$, average $)$ & 425 &
\end{tabular}

Table 1. Properties of the base fuels

All tribological measurements were carried out using the HFRR apparatus, according to the CEC F-06-A-96 method. The test temperature was $60{ }^{\circ} \mathrm{C}$ and the volume of the fuel sample used was $2 \mathrm{ml}$. Relative humidity was kept between 55 and $59 \%$, while the mean ambient temperature was $24{ }^{\circ} \mathrm{C}$. The lubricating efficiency of the fuels was estimated by measuring the average wear scar diameter WSD of the spherical specimen by using a photomicroscope. The wear scars quoted were corrected to give WS 1.4 values. The HFRR WS 1.4 parameter is the mean WSD normalized to a standard vapour pressure of $1.4 \mathrm{kPa}$. The repeatability was calculated using the following equation (1) [17]: 


$$
\mathrm{R}=139-(0.1648 \times \text { WSD1.4 })
$$

The ten essential oils used in this series of experiments, included kernel peach oil, grape seed oil, pine oil, carrot seed oil, castor oil, camomile oil, laurel oil, eucalyptus oil, lavender oil and rosemary oil. The carrot seed oil, castor oil, camomile oil, laurel oil, eucalyptus oil, lavender oil, rosemary oil were obtained from Aldrich Chemical Company and they were used as received, without further purification. However, kernel peach oil, grape seed oil and pine oil that were not commercially available and were prepared by extracting their seeds with alcohols and hexane. Afterward they were vacuum distilled to receive the final products, whose properties were similar to those reported in the relevant literature. In an effort to establish the purity of the prepared compounds, the density $d_{4}^{20}$ and the refractive index $n_{D}^{20}$ (Table 2) were compared to the corresponding data found in literature, the purity level of the compounds eventually used in this study was estimated to be at least $95 \%$ [4042]. The chemical constitution of the essential oils used in this study is complex and are mixtures of many compounds, as shown in Table 3 and 4.

\begin{tabular}{ccccc}
\hline Nomenclature & $\begin{array}{c}\text { Measured } \\
\text { density, } d_{4}^{20}\end{array}$ & $\begin{array}{c}\text { Density of pure } \\
\text { compounds, } d_{4}^{20}\end{array}$ & $\begin{array}{c}\text { Measured } \\
\text { Refractive Index, } \\
n_{D}^{20}\end{array}$ & $\begin{array}{c}\text { Refractive Index } \\
\text { of pure } \\
\text { compounds, } n_{D}^{20}\end{array}$ \\
\hline Kernel peach oil & 0.921 & 0.918 & 1.470 & 1.471 \\
Grape seed oil & 0.924 & 0.921 & 1.473 & 1.475 \\
Pine oil & 0.812 & 0.825 & 1.478 & 1.480 \\
\hline
\end{tabular}

Table 2. Chemical characteristics of pure essential oils

\begin{tabular}{|c|c|c|c|c|c|}
\hline $\begin{array}{l}\text { Chemical } \\
\text { structure }\end{array}$ & $\begin{array}{c}\text { Grape seed } \\
\text { oil }\end{array}$ & $\begin{array}{l}\text { Kernel peach } \\
\text { oil } \\
\end{array}$ & Camomile oil & Laurel oil & $\begin{array}{c}\text { Carrot } \\
\text { seed oil }\end{array}$ \\
\hline Monoterpenes & & & $\begin{array}{c}\alpha \text {-terpene } 0-10 \%, \alpha \text {-pinene } \\
0-10 \%, \beta \text {-pinene } 0-10 \%\end{array}$ & $\begin{array}{c}\alpha \text {-pinene } 4- \\
10 \%, \beta- \\
\text { pinene 3- } \\
8 \%, \\
\text { sabinene 4- } \\
12 \%\end{array}$ & $\begin{array}{c}\alpha \text {-pinene } \\
<13 \%, \beta \text { - } \\
\text { pinene } \\
<18 \%\end{array}$ \\
\hline Sesquiterpenes & & & $\begin{array}{c}\text { Sabinene } 0-10 \%, \\
\text { caryophyllene } 0-10 \%\end{array}$ & & \\
\hline Alcohols & & & $\begin{array}{l}\text { Trans-pinocarveol 5\%, } \\
\text { farnesol and nerolidod } \\
\qquad(5-6 \%)\end{array}$ & $\begin{array}{c}\text { Linalool 4- } \\
13.5 \%, \\
\text { methyl } \\
\text { eugenol } \\
12 \%\end{array}$ & $\begin{array}{c}\text { Carotol } \\
18 \%\end{array}$ \\
\hline Esters & & & $\begin{array}{l}\text { 2-methylbutyl 2-methyl } \\
\text { propionate } 0.5-25 \% \text {, } 2 \text { - }\end{array}$ & $\begin{array}{l}\alpha \text {-terpinyl } \\
\text { acetate } 10-\end{array}$ & $\begin{array}{l}\text { Geranyl } \\
\text { acetate }\end{array}$ \\
\hline
\end{tabular}




\begin{tabular}{|c|c|c|c|c|c|}
\hline $\begin{array}{l}\text { Chemical } \\
\text { structure }\end{array}$ & $\begin{array}{l}\text { Grape seed } \\
\text { oil }\end{array}$ & $\begin{array}{l}\text { Kernel peach } \\
\text { oil }\end{array}$ & Camomile oil & Laurel oil & $\begin{array}{l}\text { Carrot } \\
\text { seed oil }\end{array}$ \\
\hline 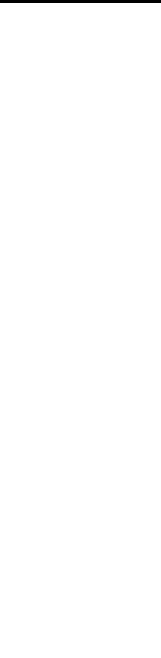 & & & $\begin{array}{c}\text { methylpropyl butyrate } 0.5- \\
\text { 10\%, 2-methylbutyl 2- } \\
\text { methyl butyrate } 0.5-25 \% \text {, } \\
\text { 2-methylpropyl 3-methyl } \\
\text { butyrate } 0-10 \% \text {, propyl } \\
\text { angelate } 0.5-10 \%, 2- \\
\text { methylpropyl angelate } 0.5- \\
\text { 25\%, butyl angelate } 0.5- \\
\text { 10\%, 3-methylpentyl } \\
\text { angelate } 0-10 \% \text {, isobutyl } \\
\text { angelate } 36-40 \% \text {, isobutyl } \\
\text { isobutyrate } 4 \%, 2- \\
\text { methylbutyl methyl-2- } \\
\text { butyrate 3\%, isoamyl } \\
\text { methyl-2-butyrate 3\%, } \\
\text { propyl angelate } 1 \% \text {, hexyl } \\
\text { acetate } 0.5-10 \%\end{array}$ & $18 \%$ & $10 \%$ \\
\hline $\begin{array}{c}\text { Phenols } \\
\text { Ketones } \\
\text { Aldehydes }\end{array}$ & & & $\begin{array}{c}\text { Pinocarvone } 13 \% \\
\text { Myrtenal 0-10\% }\end{array}$ & & \\
\hline Oxides & & & 1,8-cineole $0-25 \%$ & $\begin{array}{c}\text { 1,8-cineole } \\
30-50 \%\end{array}$ & \\
\hline Acids & $\begin{array}{c}\text { Oleic acid } \\
15-20 \%, \\
\text { linoleic acid } \\
69-78 \%, \\
\text { palmitic } \\
\text { acid } 5-11 \% \text {, } \\
\text { Stearic acid } \\
3-6 \%, \alpha- \\
\text { linolenic } \\
\text { acid } 0.3-1 \% \text {, } \\
\text { palmitoleic } \\
\text { acid } 0.5- \\
0.7 \%\end{array}$ & $\begin{array}{c}\text { Oleic acid 55- } \\
70 \%, \text { linoleic } \\
\text { acid } 17-30 \% \text {, } \\
\text { palmitic acid } \\
4-7 \% \text {, Stearic } \\
\text { acid } 1.5-3 \% \text {, } \\
\alpha \text {-linolenic } \\
\text { acid }<1.5 \% \text {, } \\
\text { palmitoleic } \\
\text { acid }<1 \% \text {, } \\
\text { arachidic acid } \\
<0.5 \% \text {, } \\
\text { eicosenoic } \\
\text { acid }<0.5 \% \text {, } \\
\text { behenic acid } \\
0.3 \%, \text { myristic } \\
\text { acid }<0.1 \% \text {, } \\
\text { margaric acid } \\
<0.1 \%, \\
\text { margaroleic } \\
\text { acid }<0.1 \%\end{array}$ & & & \\
\hline
\end{tabular}

Table 3. Chemical structure characteristics of pure essential oils used [37] 


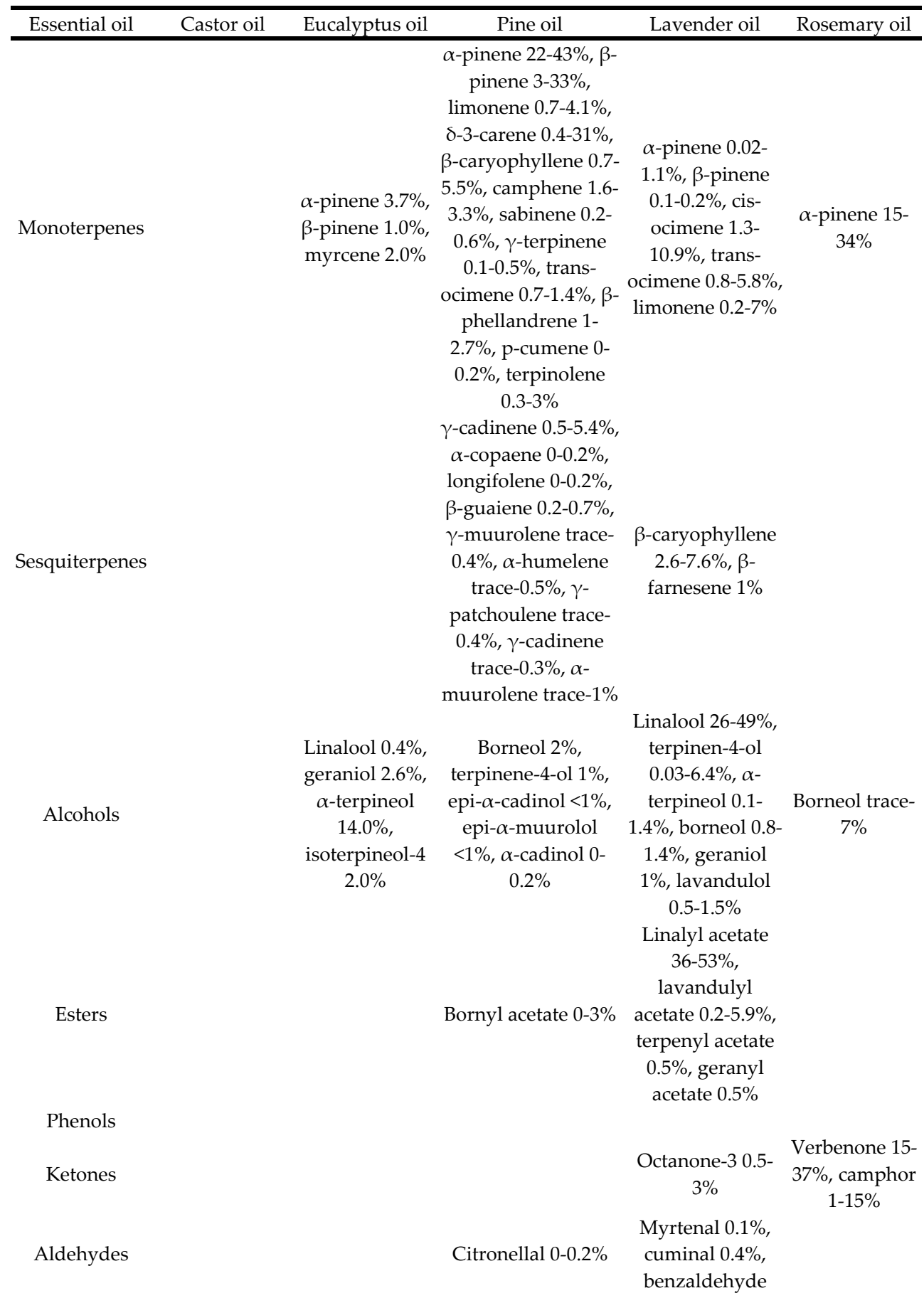




\begin{tabular}{|c|c|c|c|c|c|}
\hline Essential oil & Castor oil & Eucalyptus oil & Pine oil & Lavender oil & Rosemary oil \\
\hline Oxides & & $\begin{array}{c}1,8 \text { cineole } 62- \\
72 \%\end{array}$ & & $\begin{array}{c}0.2 \% \text {, neral and } \\
\text { genarial } 0.4 \% \text {, } \\
\text { trans- } 22 \text {-hexanal } \\
0.4 \% \\
1,8 \text { cineole } 0.5- \\
2.5 \%\end{array}$ & $\begin{array}{l}1,8 \text { cineole } \\
\text { trace- } 20 \%\end{array}$ \\
\hline 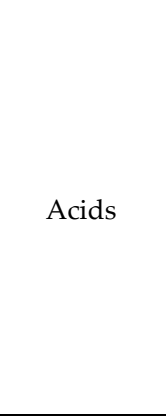 & $\begin{array}{c}\text { Ricinoleic acid } \\
\text { 85-95\%, oleic } \\
\text { acid } 2-6 \%, \\
\text { linoleic acid 1- } \\
5 \% \text {, linolenic } \\
\text { acid } 0.5-1 \% \text {, } \\
\text { stearic acid o.5- } \\
\text { 1\%, palmitic } \\
0.5-1 \% \text {, } \\
\text { dihydroxystear } \\
\text { ic acid } 0.3-0.5 \%\end{array}$ & & & & \\
\hline
\end{tabular}

Table 4. Chemical structure characteristics of pure essential oils used [37]

The ten essential oils were examined for their lubricating performance using the base fuels A1 and A2. Base fuel A1 had an average wear scar diameter (WS 1.4) of less than $460 \mu \mathrm{m}$, whereas base fuel A2 showed an increased wear scar diameter (WS 1.4) of more than 460 $\mu \mathrm{m}$. All oils were dissolved in the base fuels at the same concentration levels, i.e. 200, 500, 1000 and 5000 ppmw. The fuel properties of the pure essential oils, including their WS 1.4 values, are presented in Tables $5 \mathrm{a}$ and $5 \mathrm{~b}$.

\begin{tabular}{cccccc}
\hline Essential oil & $\begin{array}{c}\text { Grape seed } \\
\text { oil }\end{array}$ & $\begin{array}{c}\text { Kernel peach } \\
\text { oil }\end{array}$ & Camomile oil Laurel oil & $\begin{array}{c}\text { Carrot seed } \\
\text { oil }\end{array}$ \\
\hline Density $\left(\mathrm{kg} / \mathrm{m}^{3}, 15^{\circ} \mathrm{C}\right)$ & 0.924 & 0.921 & 0.929 & 0.940 & 0.923 \\
Viscosity $\left(\mathrm{cSt}, 40^{\circ} \mathrm{C}\right)$ & 29.90 & 35.56 & 28.15 & 52.05 & 32.51 \\
Potassium $(\mathrm{ppm})$ & 8 & 4 & 4 & 3 & 2 \\
Sodium $(\mathrm{ppm})$ & 1 & 2 & 2 & 2 & 1 \\
Flash point $\left({ }^{\circ} \mathrm{C}\right)$ & 165 & 326 & 55 & 56 & 51 \\
Calorific value & 10084 & 10268 & 10378 & 10227 & 10029 \\
$($ Kcal $/ \mathrm{kg})$ & 0.067 & 0.025 & 0.037 & 0.086 & 0.035 \\
Residue $(\% \mathrm{~m} / \mathrm{m})$ & 5 & 8 & 3 & 5 & 8 \\
Sulphur $(\mathrm{ppm})$ & 7 & 17 & 9 & 18 & 11 \\
Nitrogen $(\mathrm{ppm})$ & 741 & 421 & 693 & 1698 & 334 \\
Water $(\mathrm{ppm})$ & 0 & 0 & 0 & 0 & 0 \\
Ash $(\% \mathrm{~m} / \mathrm{m})$ & 152 & 117 & 169 & 217 & 237 \\
Lubricity $(\mu \mathrm{mm}$, & & & & & \\
average & & & & & \\
\hline
\end{tabular}




\begin{tabular}{cccccc}
\hline Essential oil & Castor oil & Eucalyptus oil & Pine oil & Lavender oil & $\begin{array}{c}\text { Rosemary } \\
\text { oil }\end{array}$ \\
\hline Density $\left(\mathrm{kg} / \mathrm{m}^{3}, 15^{\circ} \mathrm{C}\right)$ & 0.966 & 0.798 & 0.812 & 0.789 & 0.774 \\
Viscosity $\left(\mathrm{cSt}, 40^{\circ} \mathrm{C}\right)$ & 207.33 & 1.32 & 1.90 & 1.12 & 1.23 \\
Potassium $(\mathrm{ppm})$ & 10 & 5 & 6 & 7 & 3 \\
Sodium $(\mathrm{ppm})$ & 0 & 2 & 0 & 1 & 1 \\
Flash point $\left({ }^{\circ} \mathrm{C}\right)$ & 228 & 48 & 38 & 75 & 49 \\
Calorific value & 9854 & 9841 & 9826 & 9564 & 9339 \\
$\quad$ Kcal $/ \mathrm{kg})$ & & & & & 0.001 \\
Residue $(\% \mathrm{~m} / \mathrm{m})$ & 0.003 & 0.001 & 0.002 & 0 & 0.001 \\
Sulphur $(\mathrm{ppm})$ & 9 & 0 & 0 & 0 & 2 \\
Nitrogen $(\mathrm{ppm})$ & 3 & 0 & 3 & 201 & 167 \\
Water $(\mathrm{ppm})$ & 3035 & 126 & 57 & 0 & 0 \\
Ash $(\% \mathrm{~m} / \mathrm{m})$ & 0.010 & 0 & 0 & 350 & 462 \\
Lubricity $(\mu \mathrm{m}$, & 151 & 406 & 487 & & \\
average $)$ & & & & & \\
\hline
\end{tabular}

(b)

Table 5. Properties of pure essential oils.

\subsection{Results and discussion}

The two base fuels were initially analyzed to determine their lubrication effectiveness. The average wear scar diameter WSD values for the two base fuels are given in Table 1. It is evident that base fuel A1 has WSD value under the acceptable limit of $460 \mu \mathrm{m}$, and is characterized as fuel with good lubricating properties. Base fuel A2 has WSD value over the acceptable limit of $460 \mu \mathrm{m}$, and is characterized as fuel with poor lubricating properties. Consequently, these fuels were well suited to determine the response of essential oils on their lubrication properties.

Figure 1 shows the impact of adding essential oils on the lubricity of base fuel A1. On the basis of the HFRR test results, grape seed oil increases the lubricity of the base fuel. The WSD value decreased from $425 \mu \mathrm{m}$ to approximately $365 \mu \mathrm{m}$ at the concentration range 200$5000 \mathrm{ppm}$, the optimum value being at $1000 \mathrm{ppm}$. In the case of kernel peach oil, the WSD value decreased from $425 \mu \mathrm{m}$ to approximately $335 \mu \mathrm{m}$, the lowest value obtained again at the concentration of $1000 \mathrm{ppm}$. In the case of camomile oil, the WSD value decreased from $425 \mu \mathrm{m}$ to approximately $335 \mu \mathrm{m}$, the minimum value being exhibited at $1000 \mathrm{ppm}$. Similar behaviour if followed by carrot oil, the minimum value for lubricity being $353 \mu \mathrm{m}$. Laurel oil, decreases the WSD value from $425 \mu \mathrm{m}$ to approximately $267 \mu \mathrm{m}$ at the concentration of $5000 \mathrm{ppm}$. The addition of eucalyptus oil, causes WSD value to increase from $425 \mu \mathrm{m}$ to approximately $581 \mu \mathrm{m}$ at the concentration range 200-5000 ppm. Similarly pine oil, increases the WSD value from $425 \mu \mathrm{m}$ to approximately $543 \mu \mathrm{m}$, the minimum value being observed at $200 \mathrm{ppm}$. Lavender oil, increases the WSD value for all the concentrations examined, 


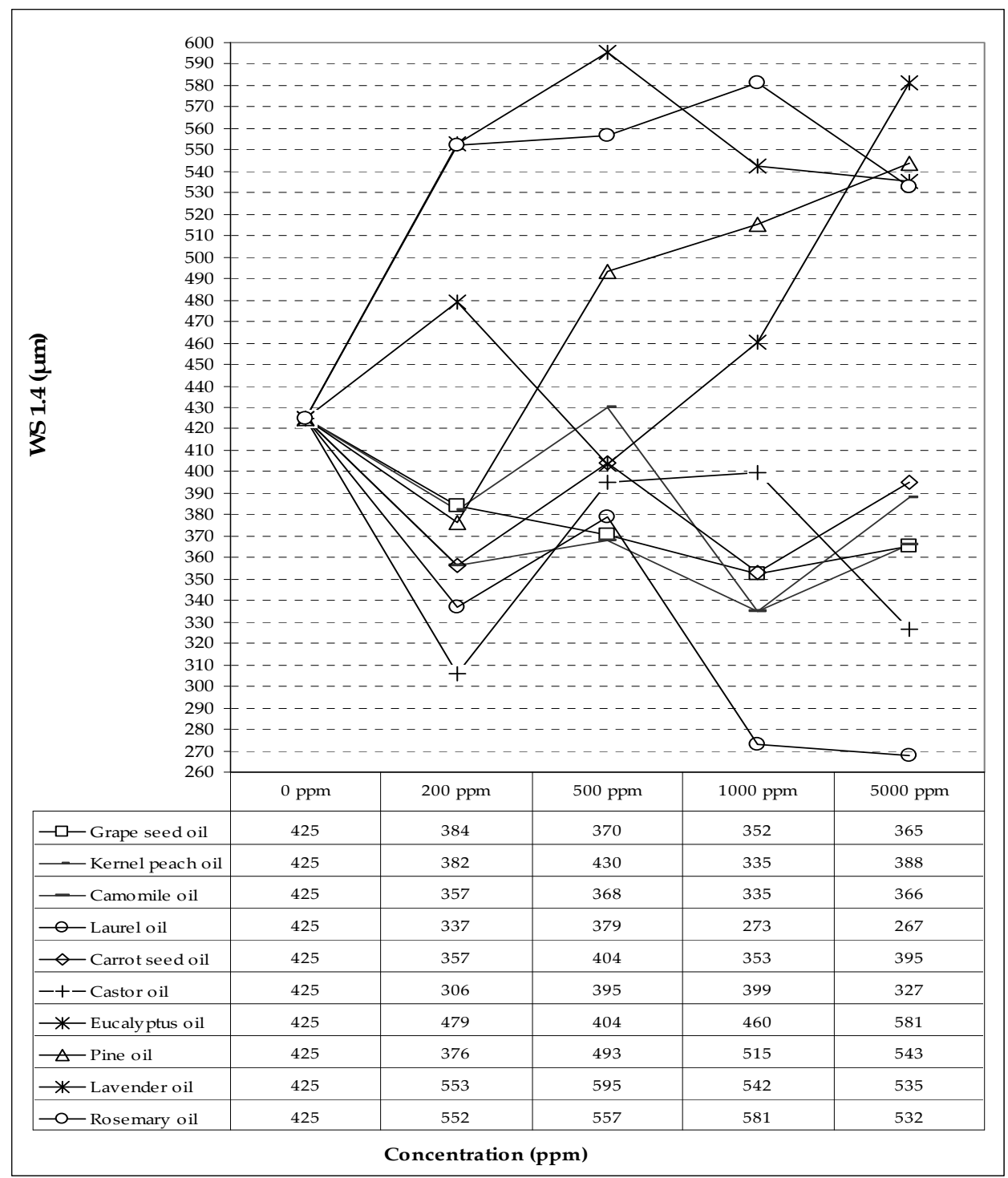

Figure 1. Impact of essential oils addition on the lubrication properties of fuel A1 
reaching a maximum at $595 \mu \mathrm{m}$. Similarly, rosemary oil increases the WSD value for all the concentrations examined. In contrast to eucalyptus oil, pine oil, lavender oil and rosemary oil, the addition of grape seed oil, kernel peach oil, camomile oil, laurel oil and carrot seed oil improved the base fuel lubricity. On the other hand, small concentrations of the pine oil and the eucalyptus oil, 200 and 500 ppm respectively, were sufficient to set the WS 1.4 value well within the required limit of $460 \mu \mathrm{m}$. However, a further increase in the concentration to $5000 \mathrm{ppm}$ for the grape seed oil, kernel peach oil, camomile oil, carrot seed oil, eucalyptus and pine oil, led to an increase in the WSD value. The analysis of the trend curves of the eucalyptus oil, pine oil, lavender oil and rosemary oil show that the required treat rate to obtain a satisfactory WSD (WS 1.4) of $460 \mu \mathrm{m}$ was $200 \mathrm{ppm}$ for the pine oil and $500 \mathrm{ppm}$ for the eucalyptus oil, while the other two oils could not obtain a satisfactory WSD of $460 \mu \mathrm{m}$ for any of the concentrations tested. If one examines the experimental data closely, it appears that the essential oils as they increase their density and viscosity, they improve their lubrication performance in the range of 200-5000 ppm.

Figure 2 gives the effect of essential oils on the tribological properties of fuel A2. It can be seen that grape seed oil, kernel peach oil, camomile oil, laurel oil, carrot seed oil and castor oil provide satisfactory HFRR mean WSD (WS 1.4) of less than $460 \mu \mathrm{m}$ at the concentration level of $200 \mathrm{ppm}$. Any further increase in the concentration of these oils led to a slight increase or decrease in the WSD values.

It should be noted that when 200 ppm of pine oil was added to the base fuel, the tribological results showed a significant improvement in WSD value of $450 \mu \mathrm{m}$. Further addition of pine oil in concentrations between 500 and 5000 ppm increased the WSD significantly.

It is evident that in order to improve the lubrication properties of low sulfur diesel fuels, small concentration levels of grape seed oil, kernel peach oil, camomile oil, laurel oil, carrot seed oil and castor oil ranging from 200 to $500 \mathrm{ppm}$ are sufficient to bring the WSD value within the required limit. In the Tables $5 a$ and $5 b$, it can be seen that lavender oil and eucalyptus oil provide satisfactory HFRR mean WSD (WS 1.4) of less than $460 \mu \mathrm{m}$ as pure essential oils, but as additives have worse lubricating properties. Similar conclusions may be drawn if one considers the chemical constitutions of eucalyptus oil, pine oil, lavender oil and rosemary oil where the terpenes (monoterpenes and sesquiterpenes) and oxides (1,8-cineole) do not help in the direction of improving the lubricating ability of essential oils, Table 3. In contrast, essential fatty acids play an important role providing better lubricating performance (castor oil, kernel peach oil and grape seed oil). In general, esters seem to appear a better lubricating performance as their density increases.

Overall, it appears that the essential oils having higher density and viscosity improved their lubrication performance in the range of 200-5000 ppm. 


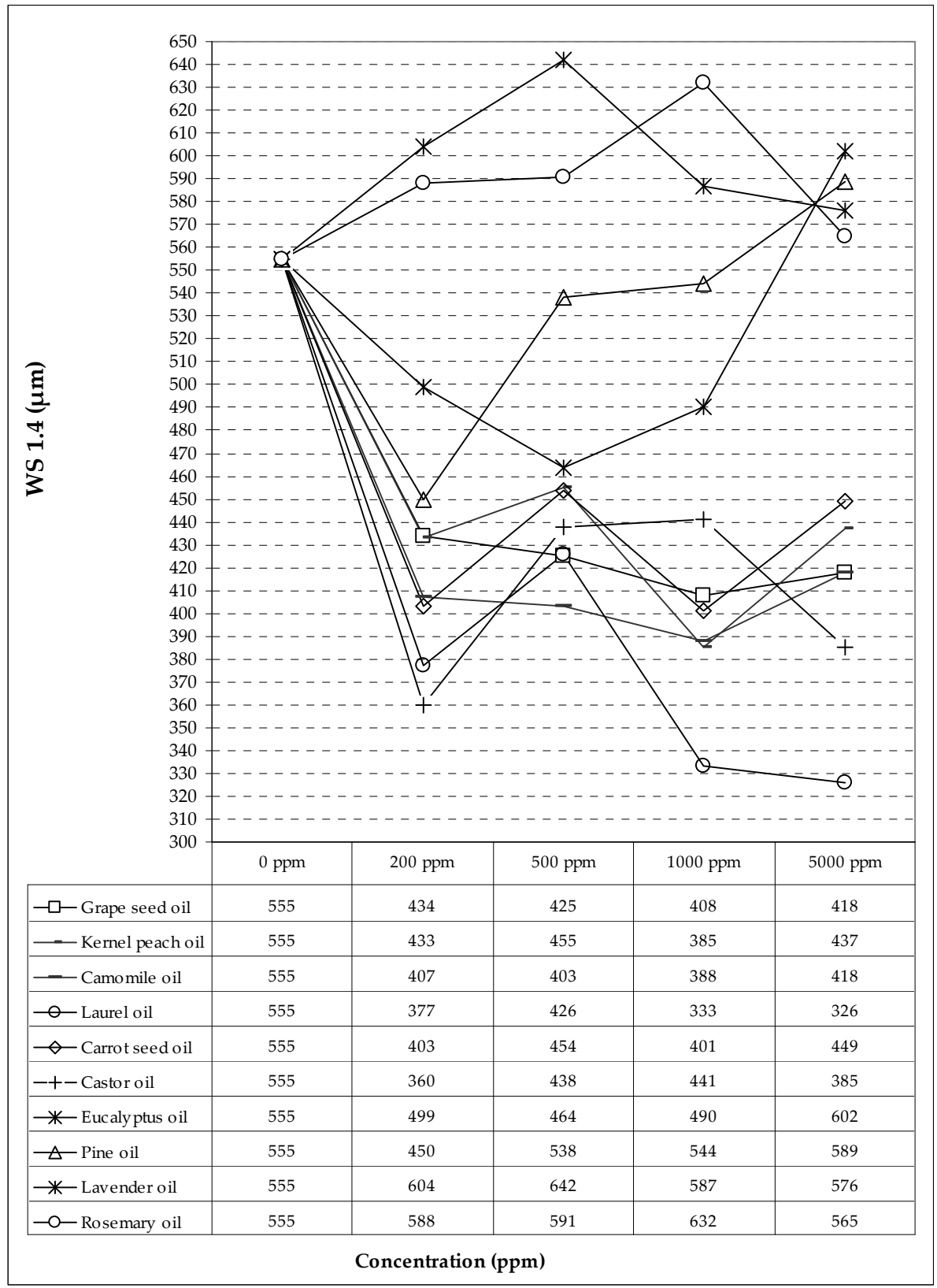

Figure 2. Impact of essential oils addition on the lubrication properties of fuel A2 


\section{Gasoline fuel lubricity}

Gasoline lubricity is a complex phenomenon, involving many complicated and interconnecting factors, such as the presence of water, oxygenates diolefins, diaromatics, the effect of viscosity and the synergistic effect of different wear mechanisms. The lubricity mechanism of gasoline is quite different from that of diesel fuels that leads to severe adhesive wear. With low-sulphur fuels, adhesive wear is observed instead of corrosive and mild oxidative wear, and deposits build up on top land.

Metallurgy and mechanical properties of test specimens have important effects on the lubricating mechanisms of fuels. When the hardness of the lower specimen in an HFRR test is not enough to support the generated oxide films formed by the reaction between surfaces and dissolved oxygen and the adsorption films formed on top of the oxide films by gasoline polar impurities, severe adhesion and metal transfer occur.

Fuel quality in recent years became increasingly important, not only for its role in the actual performance of the vehicles, but also for its impact on the emissions. However, the fuel pump at the service stations is the point at which the actual specifications of the fuels should be ascertained [43]. In this chapter, results are presented on the gasoline properties impact on lubricity, based on the study of numerous petrol samples.

\subsection{Experimental procedure}

The two principal problems in testing gasoline regarding the lubricity, are evaporation of gasoline fuel due to its very high volatility and the extreme sensitivity of gasoline lubricity to tiny amounts of contaminant. Researchers have recently reached to the solution to modify the conventional HFRR test method for studying diesel fuels, principally by deepening the fuel holder so that a larger sample of fuel could be accommodated and by covering the lubricant test chamber with a close-fitting lid. The test rig is also completely enclosed in a plastic box from Polytetrafluoroethylene (PTFE). This enabled the humidity of the test to be controlled, a factor that has been shown to influence wear of fuels, and also helped retain gasoline vapors.

The test conditions used for the gasoline tests were chosen to be identical to those specified for diesel fuel tests according to ISO 12515-1 except for the fuel temperature. A fuel temperature of $25^{\circ} \mathrm{C}$ was employed in all gasoline tests. It is important to mention that fuel tests were carried out in compliance with the standard ASTM G 133 as there is not as yet a standard for gasoline lubricity.

The following gasoline properties were determined since they are directly related to the exhaust emissions: Research Octane Number (RON), Benzene, Toluene, Xylene, Olefins, Saturates, MTBE and Total Aromatics were determined using the mid-IR method, while Sulfur and Nitrogen content was measured using the ANTEK 9000NS elemental analyser according to ASTM D 5453 and ASTM D 5762 respectively. Gasoline vapour pressure 
measurements were conducted with a Setavap Vapour Pressure tester 22420-3. The Setavap Vapour Pressure results were converted to DVPE in strict conformance with the requirements of ISO 3007 method, using the appropriate conversion equation. Potassium content (an additive used in lead replaced gasoline (LRP) to protect valve seat recession) was measured using the Atomic Absorption Spectrometry (AAS) according to IP 456. Viscosity was determined at $15^{\circ} \mathrm{C}$ and $25^{\circ} \mathrm{C}$ using the Anton Paar viscometer by ASTM D 7042. Distillation data including the value of residue were obtained according to the procedure of ISO 3405. Also, the ISO 10370 method was used for the calculation of residue and the examination of adulteration with heavier distillates or solvents. It should be mentioned that sulphur content is a physical marker concerning the matter of gasoline adulteration with heavier distillates of petroleum. Water content and conductivity $\left(\right.$ at $\left.20^{\circ} \mathrm{C}\right)$ were also measured according to the standards ISO 12937 and ISO 6297, respectively. Also, Total Acid Number (TAN) was measured according to the standard ISO 7537. The TAN value might indicate the potential of corrosion problems.

One hundred twenty six (126) samples of commercial gasolines were collected from service stations located all over Athens and its suburbs. They consisted of 40 samples of LRP gasoline, 46 samples of unleaded gasoline and 40 samples of super unleaded. The analysis of the samples showed that 19 samples were found to be adulterated ( 3 unleaded, 10 LRP and 6 super unleaded). Also, thirty six (36) samples of non-additized gasolines were tested, which were produced by mixing in different proportions the following refinery streams: FCC, Isomerate, Alkylate, Dimate, Reformate, MTBE and ETBE which were obtained by the Hellenic Petroleum refinery installations in 2005. The above samples were not randomly classified during their preparation but they stemmed from a multivariate analysis of variance and an appropriate empirical and statistical process to evaluate and predict the values of Research Octane Number, density, vapour pressure and benzene content $(<1 \%$ $\mathrm{v} / \mathrm{v}$ ) of the final mixtures.

Gas chromatography was applied to the quantitative determination of paraffins, isoparaffins, olefins, naphthenes and aromatics with 3 to 12 carbon atoms according to the standard methodology described by CAN/CGSB-3.0 No. 14.3M93.

Emphasis was given to the experimental procedure because of the amount of samples and properties measured, in order to ensure that no contamination or lighter substances loss would influence the final result of the measured values. The values of the properties were statistically analyzed and compared as a completely randomized factorial experiment to assess whether and how the different type of gasoline fuel and the measured properties affect the lubricity using analysis of variance and complex neural networks $[35,36]$. The lubricating properties of gasolines were expressed from the value of mean wear scar diameter (MWSD1.4) of the spherical specimen, detected using a photomicroscope to an accuracy $\pm 1 \mu \mathrm{m}$ and were corrected at the absolute water pressure $1.4 \mathrm{kPa}$ at the temperature of $25^{\circ} \mathrm{C}$. It was found that the sensitivity to humidity of friction, wear and film formation of gasoline and diesel is quite different in different humidity ranges. In the range 
of water vapour pressure less than about $0.8 \mathrm{kPa}$, wear increases rapidly with humidity and then remains insensitive to humidity with increasing humidity. This phenomenon may suggest the presence of a transition concentration of dissolved water in gasolines.

The appearance of the transition may be explained by different effects of dissolved water on the lubricity performance of fuels themselves, oxide film formation in rubbing surfaces, as well as the interfacial chemistry of protective film formation by naturally-occurred antiwear agents in fuels. The results of previous studies suggest that the influence of humidity on the measurement of friction, wear and film formation of fuels can be, at least to a large extent, eliminated by carefully controlling humidity in a certain range, say from 0.9 to $1.2 \mathrm{kPa}$.

The optical assessment of the wear and the possible wear mechanisms that took place during the experimental process, were evaluated with back scattered electron imaging, quantitative $x$-ray analysis, and x-ray mapping of the surface of the metal specimens using SEM technique (Scanning Electronic Microscope). Additionally, the samples were photographed using scanning probe microscopy for the metal surfaces.

\subsection{Results and discussion}

\subsubsection{Gasoline lubricity evaluation}

Examination of the gasoline lubricity has shown that the majority of the samples for the 36 non-additized gasoline fuels were above the acceptance limit of diesel lubricity, the 460$\mu \mathrm{m}$ limit. The values ranged from $711 \mu \mathrm{m}$ to $1064 \mu \mathrm{m}$ as shown in Figure 3 . The preliminary results on a non-additized gasoline showed that the repeatability of the modified HFRR test is quite good. The tested samples were evaluated three repeated times, in order to obtain the mean lubricity value. The commercial gasolines were evaluated twice, to obtain their mean lubricity value. Their values ranged from $279 \mu \mathrm{m}$ to $846 \mu \mathrm{m}$ as shown in Figure 4. On the contrary, most of the samples of LRP gasoline were near the limit of $460-\mu \mathrm{m}$ indicating that the presence of the potassium additive had a main effect on the lubricating properties of fuels. The limit of 460-limit is even lower if we consider the reduction of temperature to $25^{\circ} \mathrm{C}$ (about $400 \mu \mathrm{m}$ ). Adulterated new super gasolines with unleaded gasoline have poorer lubricating properties, as shown in Figure 4. It is obvious that unleaded and super unleaded gasolines have much higher lubricity values than LRP gasolines. Especially, samples with sulphur content below $50 \mathrm{ppm}$ and nitrogen content below $10 \mathrm{ppm}$, exhibit extremely high lubricity values above the limit of $700 \mu \mathrm{m}$ after appropriate statistical analysis (Factor Analysis, Two-step cluster analysis and Neural network approach).

There was no linear or other type of correlation between the concentration of potassium and the lubricity, but after statistical approach, emerges that with a concentration above $5 \mathrm{ppm} \mathrm{K}$ there may be a significant reduction of MWSD1.4 value near the limit of $460 \mu \mathrm{m}$, as shown in Figure 5. The factors most likely to cause the observed differences in lubricity are the bulk fuel composition, the use of additives and the use of oxygenates. 


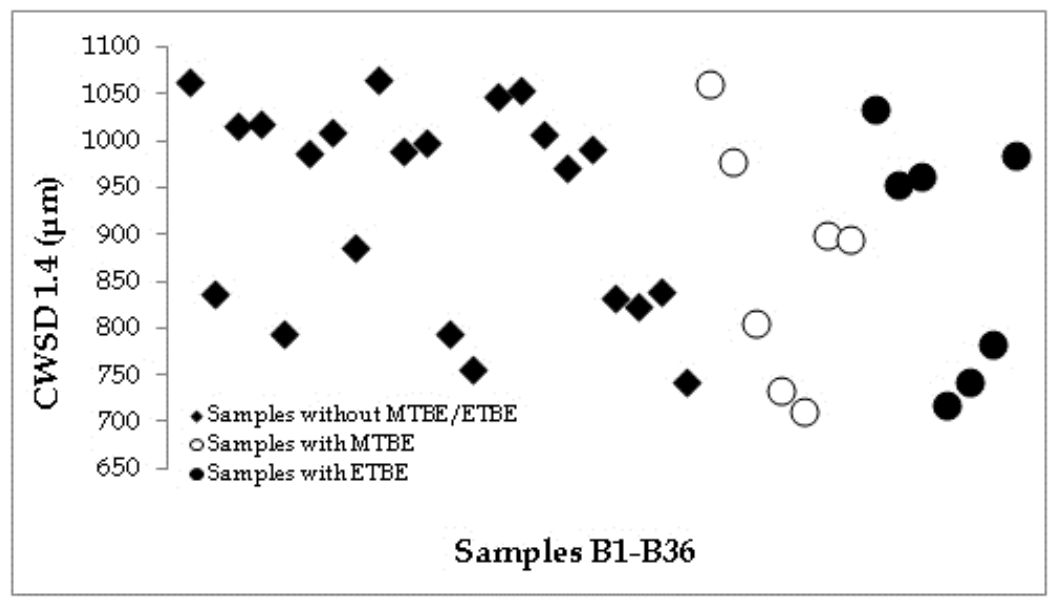

Figure 3. Lubricity mean values (CWSD1.4 - Corrected Wear Scar Diameter at $1.4 \mathrm{kPa}$ water pressure) for the non-additized gasoline samples B1-B36.

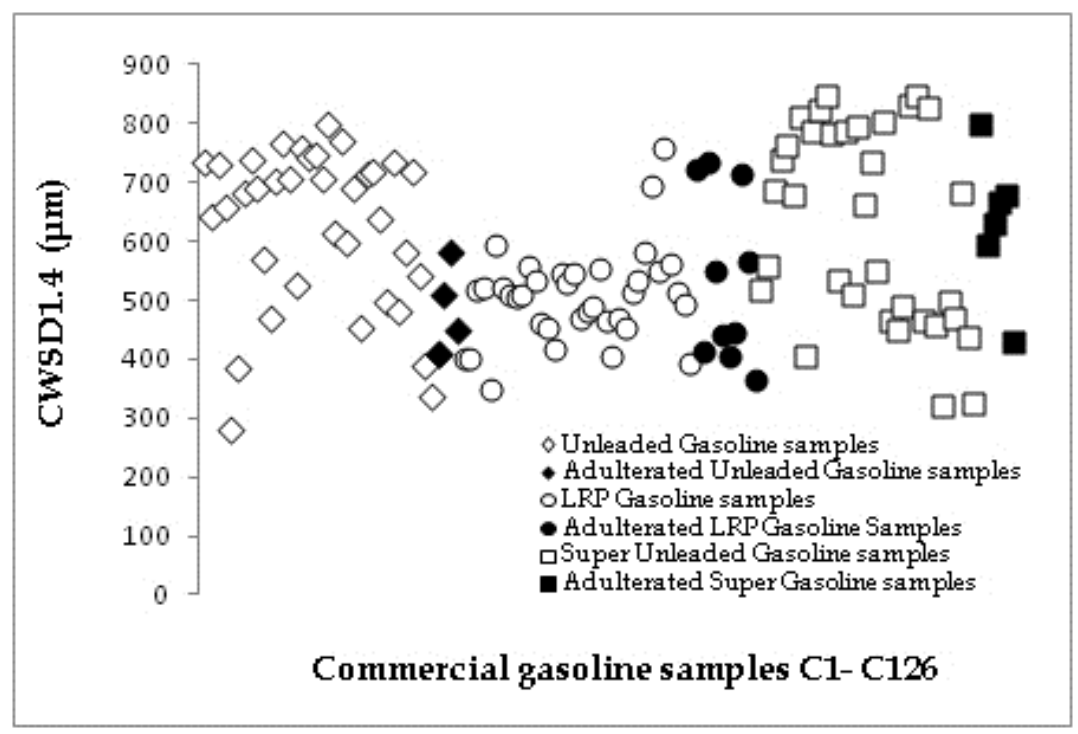

Figure 4. Gasoline lubricity mean values (CWSD1.4 - Corrected Wear Scar Diameter at $1.4 \mathrm{kPa}$ water pressure) for the three commercial types (Unleaded, Super Unleaded and LRP). 


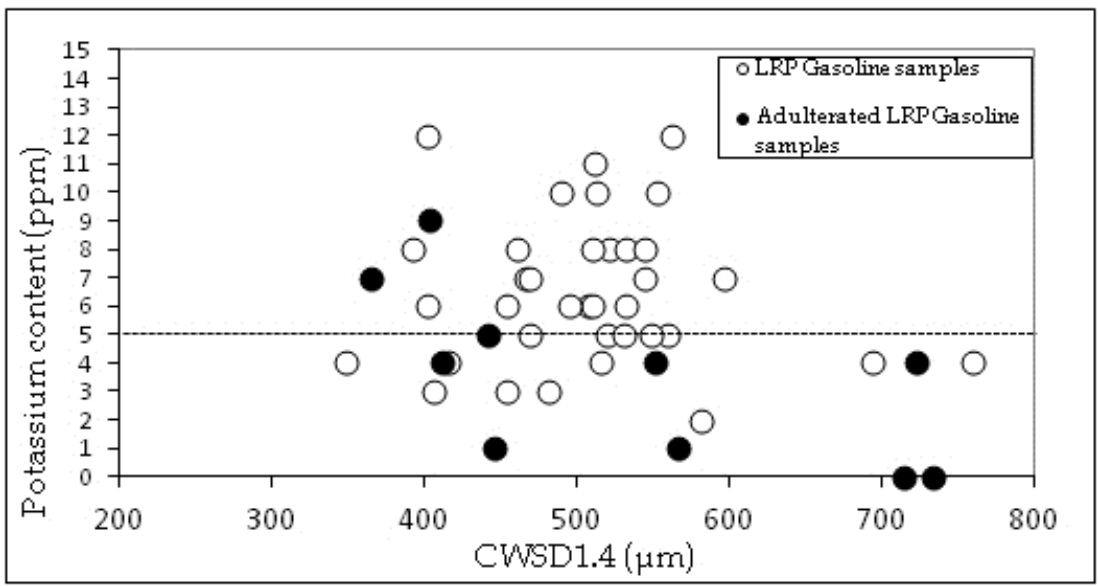

Figure 5. Potassium content of LRP gasoline fuels versus lubricity (CWSD1.4)

The diagrams for the variation of the lubricity values with the coefficient of friction and film are shown in Figures 6 and 7 respectively. In Figure 5, there appears a linear correlation between the gasoline lubricity and the coefficient of friction for the whole series of the samples, non-additized and commercial samples $\left(\mathrm{R}^{2}=0.85\right.$ and 0.88 respectively). This strong linear relationship between the coefficient of friction and lubricity is due to the wear mechanism of the gasoline fuel and especially adhesive wear which is the most basic subcategory observed. In Figure 7, two regions were observed according to the variation of the film in relation to the lubricity values. The repeatability limits $(R)$ for these two regions can be calculated according to the following equations $(2,3)$ which resulted from statistical and mathematical analysis, while the limit in which this difference was observed at the variation of the film with the lubricity values concure to the mean value of lubricity for the commercial samples:

$$
\begin{aligned}
& \text { If MWSD1. }>589 \mu \mathrm{m} \text {, then } \mathrm{R}=137-0.0854 \times \text { MWSD1.4 } \\
& \text { If MWSD1.4 } \leq 589 \mu \mathrm{m} \text {, then } \mathrm{R}=137-0.1094 \times \text { MWSD1.4 }
\end{aligned}
$$

A possible explanation for the formation of two film categories, maybe the severe adhesive wear and metal transfer occurring in the unleaded, super unleaded and adulterated gasolines, exhibited in Figure 7 as the lower plateau.

\subsubsection{Gasoline fuel comparison}

The adulterated fuel samples were isolated and two statistical computations were carried out each time, one with these adulterated samples and the other without them. The spread of the values can be depicted using box-plots. Figure 8 shows the median, quartiles, and extreme values of lubricity for each type of gasoline fuel. Each box plot displays the $50 \%$ percentage of samples' population in the square area, the $75 \%$ percentage of them within the 


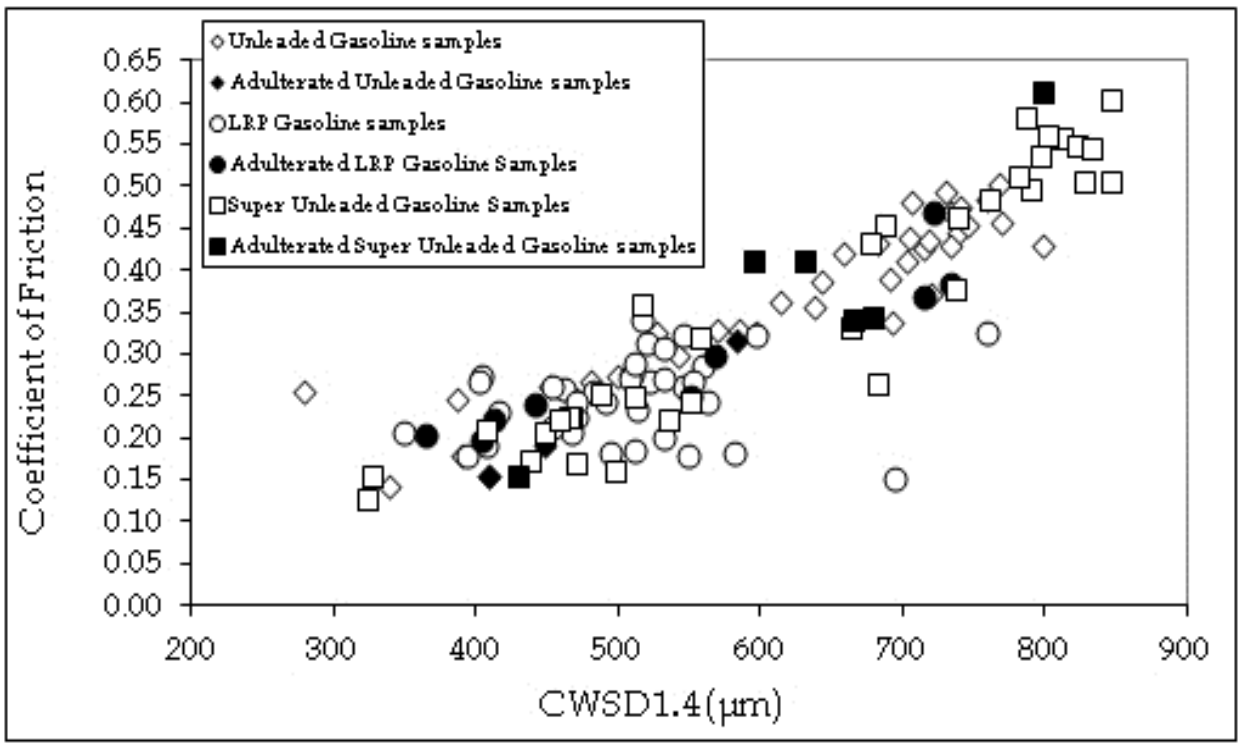

Figure 6. Gasoline lubricity mean values (CWSD1.4) versus coefficient of friction for 126 commercial gasoline fuels.

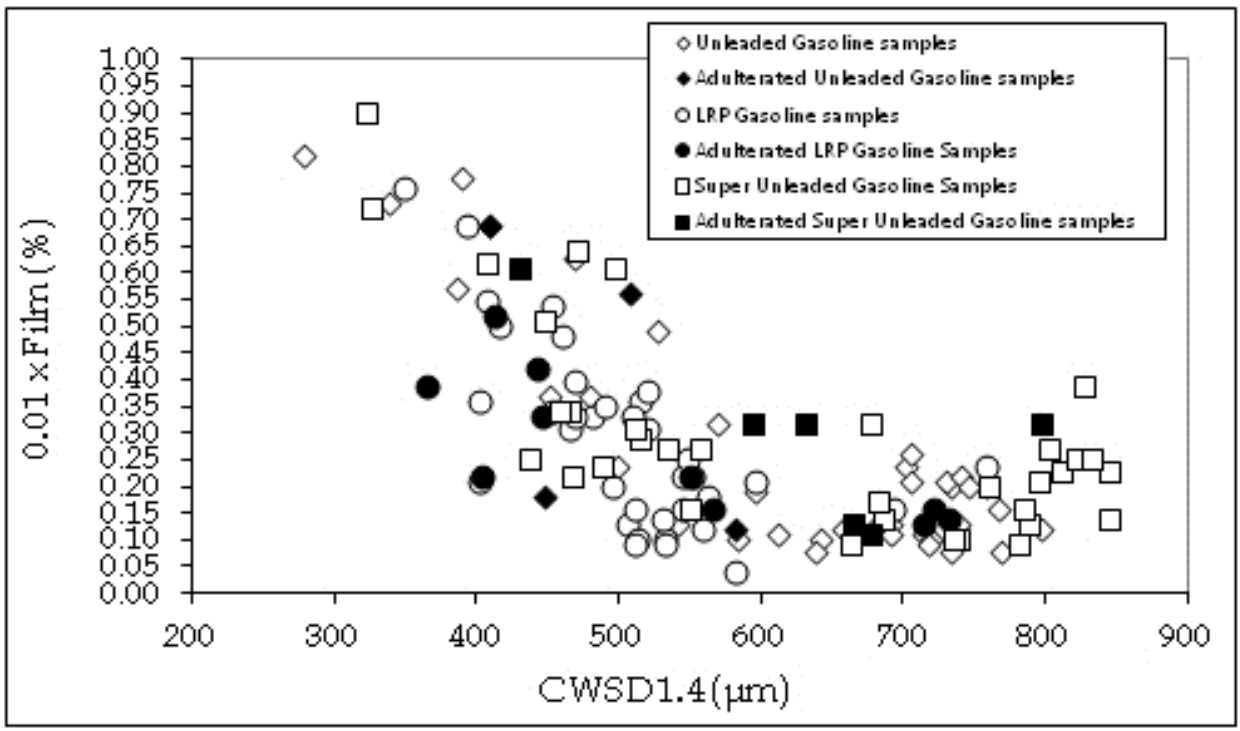

Figure 7. Gasoline lubricity mean values (CWSD1.4) versus film for 126 commercial gasoline fuels. 


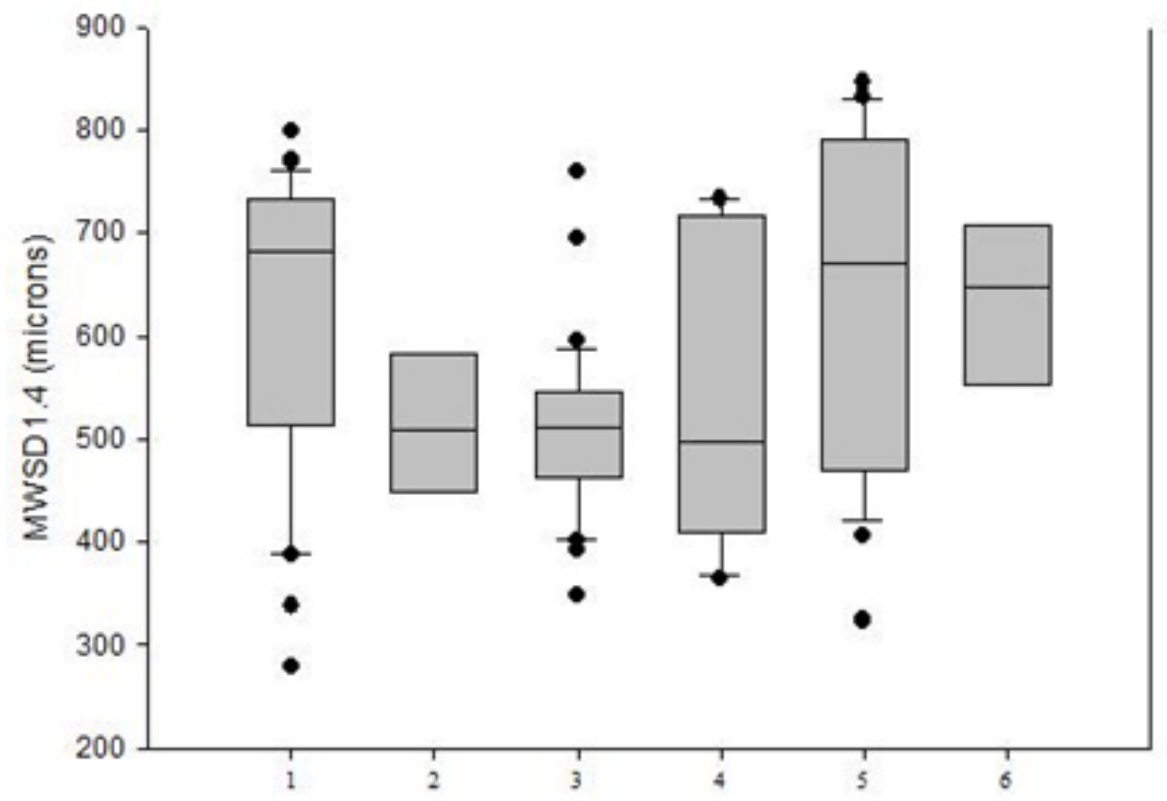

Figure 8. Box plot analysis - First statistical graphic approach to the data (1=Unleaded, $2=$ Adulterated Unleaded, 3=LRP, 4=Adulterated LRP, 5=Super Unleaded, 6= Adulterated Super Unleaded).

upper and lower limit and the extreme values which are cases with values more than 3 box lengths from the upper or lower edge of the box. It is shown that LRP gasolines have a much better representative sample population indicating good lubricating properties compared with the other two types of gasoline. One unleaded gasoline has shown extreme good lubricity value, $279 \mu \mathrm{m}$, but it is assumed to be caused by the use of special anti-wear or other additives. Because all the properties were not normally distributed for correlation analysis with Pearson correlation coefficient, the correlation coefficients of Spearman and Kendall's tau-b were chosen to be computed. The effect of the properties on the gasoline lubricity is different for each type of gasoline. The chemical structure and the related individual physical properties seemed to inter-correlate in their effect on lubricity in different degree for each type of gasoline.

More specifically, the statistically significant coefficients showed that unleaded gasoline samples appear to have lower values of wear diameter, as sulphur and nitrogen content, saturates and viscosity increased. On the contrary, unleaded gasolines appear to have greater values as toluene, oxygen, MTBE and vapor pressure increased.

LRP gasolines appear to have lower values of wear diameter as sulphur, potassium and nitrogen content, conductivity (non-adulterated samples), saturates and viscosity increased. On the contrary, LRP gasolines appear to have greater values as the total acid number, benzene, aromatics and xylene is increased. 
Finally, super unleaded gasolines appear to have lower values of wear as sulphur content, nitrogen content and olefins increased. On the contrary, super unleaded gasolines seem to have greater values as toluene, xylene, water, benzene, aromatics and oxygen increased.

Linear regression and categorial regression was applied for each type of commercial gasoline fuel and was concluded that the gasoline lubricity values could be predicted accurately by models if we know at least 15 to 20 physicochemical and constituent characteristics of the fuels measured for the commercial and non-additized gasoline samples, excluding the tribological characteristics such as the coefficient of friction, film and absolute water pressure.

Neural network approach showed that the concentration of cyclic olefins with 6,7,8,9 and 11 carbon atoms and normal olefins with 5 and 8 carbon atoms increases with the lubricity, while the concentration of normal paraffins with 4,7,9,10 and 11 carbon atoms decreases with the lubricity. Also, it was confirmed that the percentage of dimate stream, the concentration of total normal olefins $(\% \mathrm{w} / \mathrm{w})$ and the concentration of olefins $(\% \mathrm{v} / \mathrm{v})$ increases with the lubricity, as shown in Figure 9.

Numerical analysis for the refinery streams that were blended together in order to evaluate the gasoline lubricity of non-additized gasoline fuels showed the optimal proportions for each stream which lead to a minimum lubricity as shown in Table 6 . We conclude that a percentage of 8 to $9 \% \mathrm{v} / \mathrm{v}$ of oxygenate such as MTBE and ETBE with the an optimum composition for the rest streams can give us a minimum lubricity and an increase in the percentage of isomerate stream in contrast with FCC and reformate stream proportions which would lead to a minimum lubricity, taking into account the modern refinery practice used.

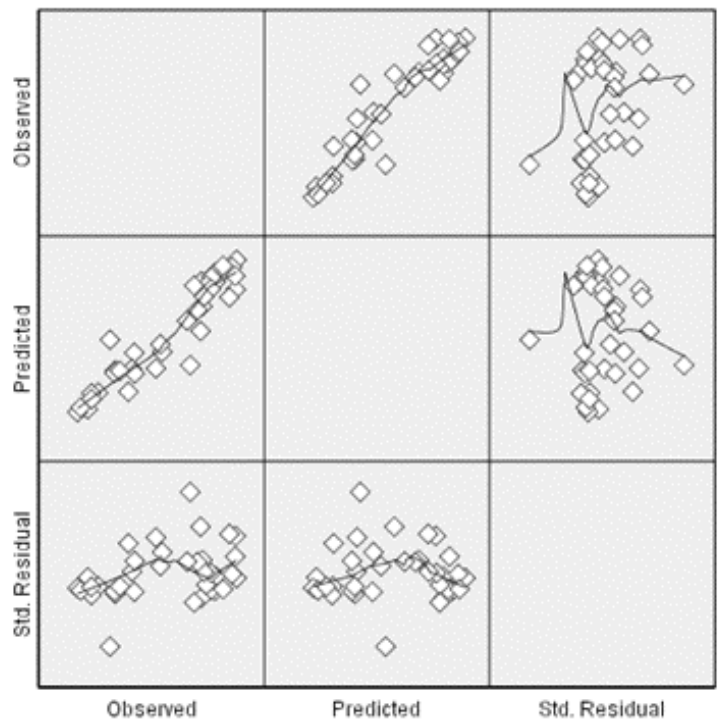

Figure 9. Predicted and observed values showing a linear effect of the percentage of dimate stream, the concentration of total normal olefins ( $\% \mathrm{w} / \mathrm{w})$ and the concentration of olefins $(\% \mathrm{v} / \mathrm{v})$ on lubricity mean values (CWSD1.4). 


\begin{tabular}{|cccc|}
\hline & & \multicolumn{2}{c|}{ Addition limits } \\
\cline { 3 - 4 } & $\begin{array}{c}\text { Optimum percentage of } \\
\text { addition }\end{array}$ & max & min \\
\hline Reformate & 0.26 & 0.50 & 0.11 \\
FCC & 0.35 & 0.50 & 0.20 \\
Alkylate & 0.10 & 0.15 & 0.00 \\
Dimate & 0.00 & 0.05 & 0.00 \\
Isomerate & 0.21 & 0.30 & 0.10 \\
MTBE or ETBE & 0.09 or 0.08 & 0.13 & 0.00 \\
\hline
\end{tabular}

Table 6. Data of numerical analysis for optimum percentage of addition.

\subsubsection{Viscosity and density effect}

There is no specification limit for the viscosity of gasoline fuels. It was decided to test all the samples at the temperatures of $15^{\circ} \mathrm{C}$ and $25^{\circ} \mathrm{C}$. During the statistical process, a linear correlation between the viscosity and density appeared $\left(R^{2}=0.92,0.98\right.$ and 0.90 for unleaded, LRP and super unleaded samples respectively). Figure 10 shows the correlation between density and viscosity for all the gasoline samples for each type separately. Both these properties are greatly influenced by the composition of the fuel.

This enhances the fact that the compositional characteristics of the fuel do influence the gasoline lubricity to a considerable degree, but there is not any linear or other correlation between density and viscosity with lubricity.

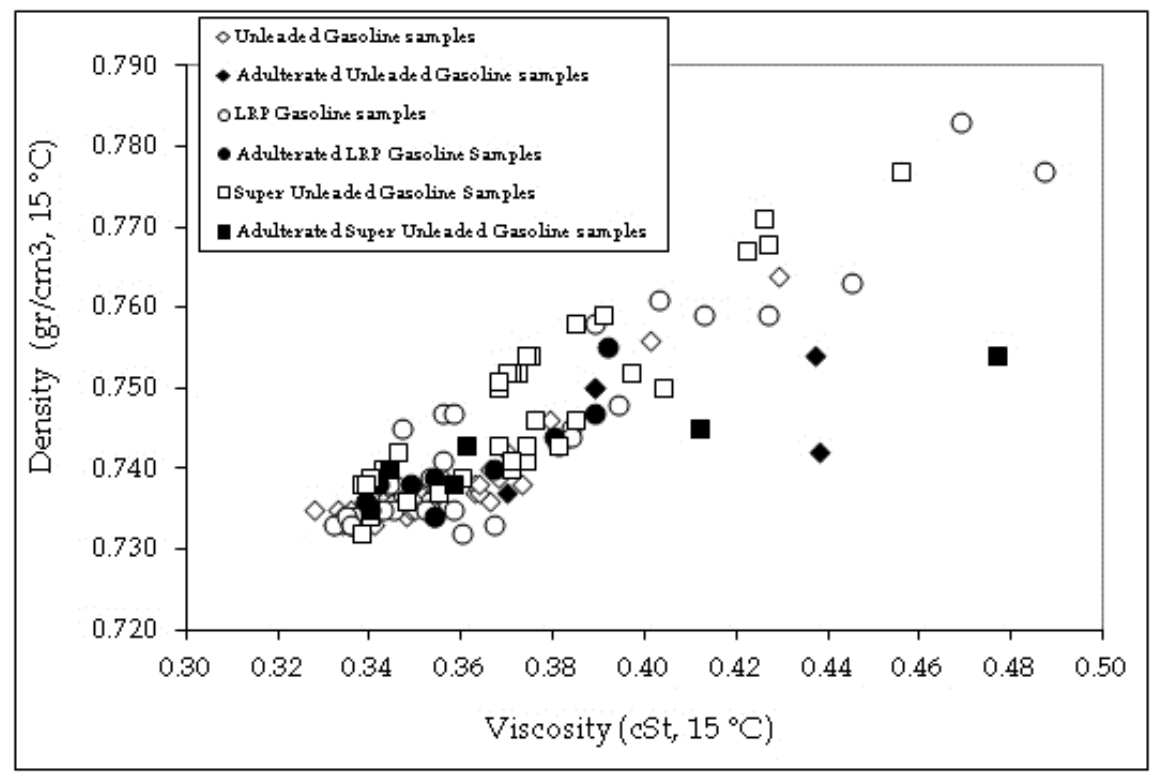

Figure 10. Graphs indicating linear correlation between viscosity and density at $15^{\circ} \mathrm{C}$. 


\subsubsection{Scanning electron microscopy results}

The quantitative $x$-ray analysis of SEM showed the existence of the elemental chlorine in six of the nine cases. The level of the chlorine content was greater than the potassium content which was detected using the same technique. There is strong evidence that the level of concentration for the chlorine in the gasoline fuels varies from 0.1 to few ppm as potentiometric titrations revealed (ASTM D 4929). Only very small quantities of impurities containing chlorine are present in gasolines but they can chemically react with the metal surface under high pressure conditions. The activity of halogenated hydrocarbons increases with decreasing stability of the carbon-halogen bond. At local contact temperatures ranging between $305-330{ }^{\circ} \mathrm{C}$, the additive thermally decomposes and the reactive halogen atoms form a surface layer of iron halogenides on the part surface. Eventual failure of the contact point comes when the contact temperature exceeds the melting point of the iron halide layer. Under such conditions, small particles of carbon are generated as well.

More elements were detected, such as $\mathrm{K}, \mathrm{Fe}, \mathrm{S}, \mathrm{Si}, \mathrm{Cl}, \mathrm{Cu}, \mathrm{Cr}$ and $\mathrm{Mn}$ in accordance with the preliminary data of the elemental analysis for the specific batch of specimens that were used apart from the sulfur concentration which originated from the fuel constituents.

It was observed that the material first transferred to the ring was a disc grey layer which then oxidized and detached as fine brown powder, either haematite $\left(\alpha-\mathrm{Fe}_{2} \mathrm{O}_{3}\right)$ or hydrohaematite $\left(\alpha-\mathrm{Fe}_{2} \mathrm{O}_{3} . \mathrm{nH}_{2} \mathrm{O}\right.$ ). Three wear processes were suggested: (a) transfer of metal from ball to disc, (b) oxidation of transferred layer and (c) removal of the oxide as detached debris.

In the HFRR tests in the current study, a ball-on-flat contact geometry was used, similar to those described above. However the upper specimen is hard, 750 850 VPN $\left(\mathrm{kg} / \mathrm{mm}^{2}\right)$ and lower specimen, soft 190 210 VPN. In such a system, strong adhesion transfers material from soft to hard specimen. Oxidation, or probably severe cold working, will then transform the layers into hard abrasive lump or debris.

In HFRR tests, strong adhesion resulted in transfer of the material of soft flat specimen to the hard ball specimen and the transferred layers then formed wear particles. Therefore, abrasive wear is a wear process secondary to adhesive wear. The key property a material needs to resist abrasive wear is hardness. Moisture also has a strong influence on abrasive wear rates. Usually, abrasive wear rate increases with increasing moisture content.

In the case of gasolines, the corrosive medium can consist of gasoline components, additives, dissolved water or dissolved oxygen for corrosive and oxidative wear. Except for trace amount of polar impurities the most chemically-active gasoline components are olefins, including monoolefin and diolefins.

The severe adhesive wear in gasolines can be depressed by adding moderately reactive additives, such as corrosion inhibitors. The minimum gasoline wear can probably be obtained by carefully selecting the corrosivity of antiwear additives to balance adhesive wear/corrosive wear. In the case of gasoline, three different types of wear, i.e. adhesive wear, abrasive wear and corrosive wear persist together and probably interact synergistically. 
The amount of oxygen and water dissolved in gasoline fuels is quite important. The mean value for water content was $208 \mathrm{ppm}$ (maximum value $618 \mathrm{ppm}$ and minimum $64 \mathrm{ppm}$ ) and the mean value for oxygen content was $1.07 \% \mathrm{w} / \mathrm{w}$ (maximum value $2.87 \% \mathrm{w} / \mathrm{w}$ and minimum $0.14 \% \mathrm{w} / \mathrm{w}$ ). In most cases, the water absorbed by gasolines from the atmosphere reached the water solubility in gasoline. Therefore if humidity increases further, the water content in gasolines does not increase, so neither does the wear.

Figures 11 and 12 depict the wear mechanisms mentioned above.

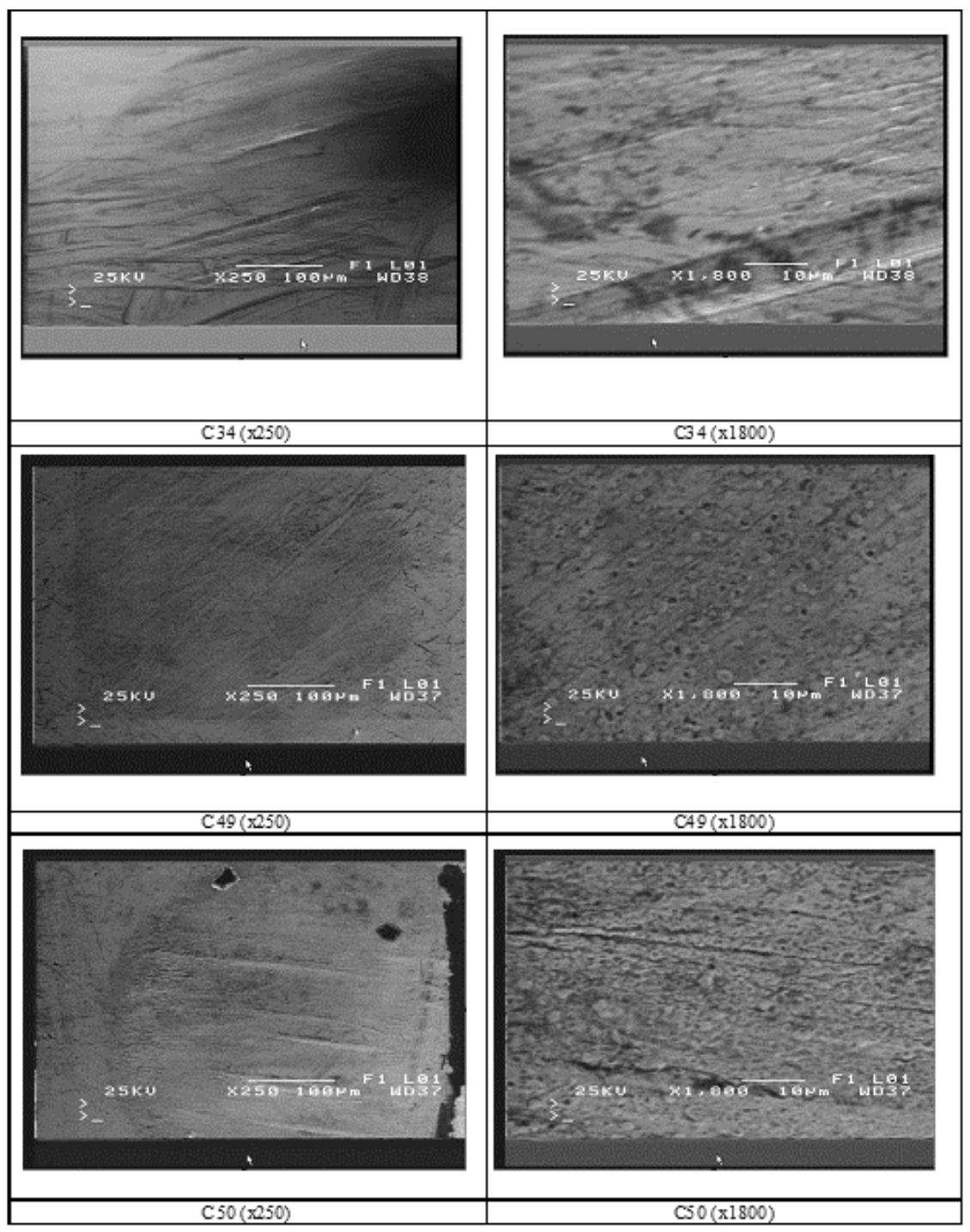

Figure 11. SEM images for commercial gasoline samples. 


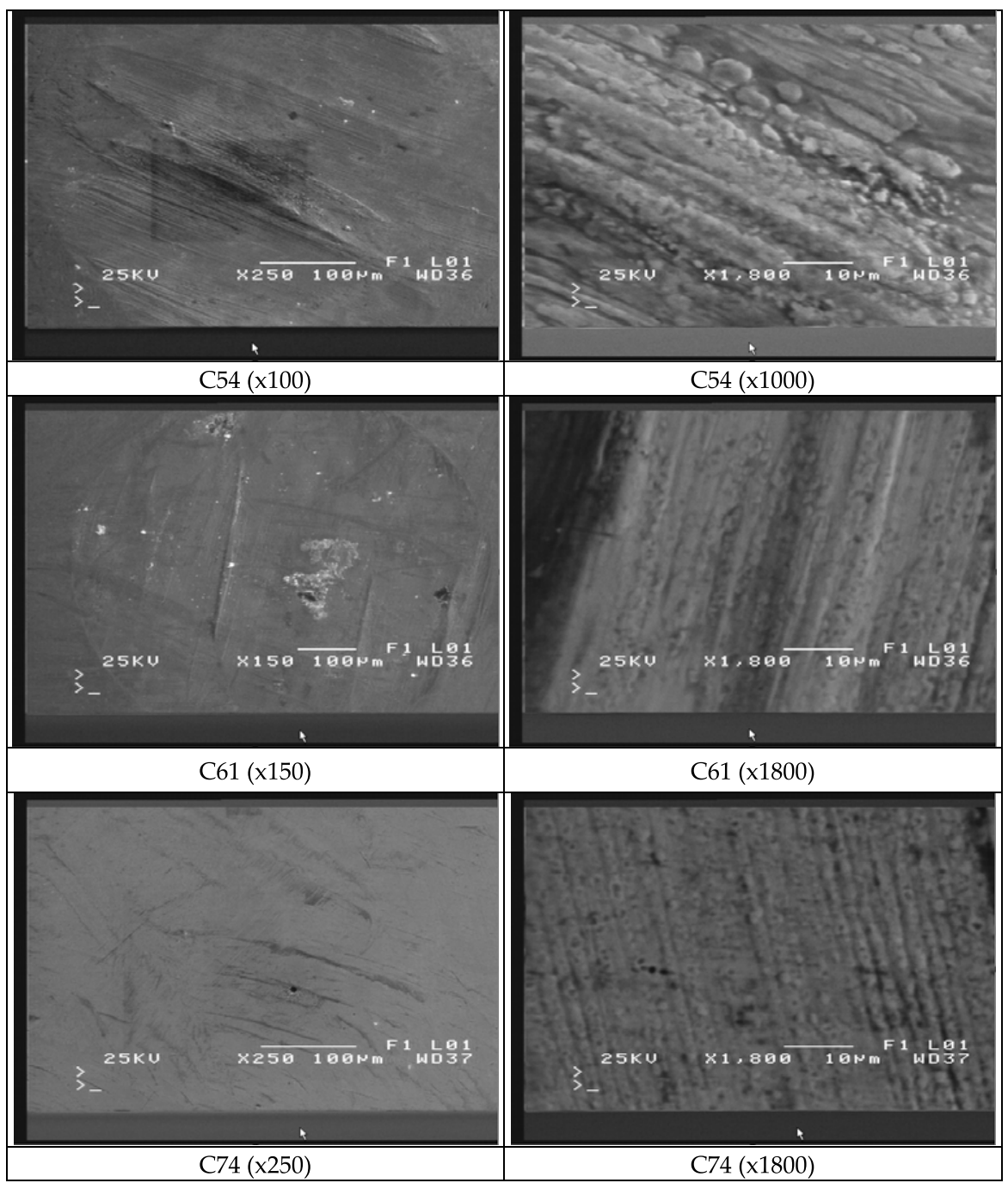

Figure 12. SEM images for commercial gasoline samples.

\section{Conclusions}

In an effort to investigate the impact of essential oils on the tribological properties of low sulfur diesel fuels, ten essential oils were added to low sulfur fuels. The following conclusions can be drawn from this study:

1. Six of the ten essential oils used, i.e. grape seed oil, kernel peach oil, camomile oil, laurel oil, carrot seed oil and castor oil provided satisfactory HFRR mean WSD (WS 1.4) of less than $460 \mu \mathrm{m}$, for concentration levels between 200 and 5000 ppm. 
2. The other four essential oils, i.e. eucalyptus oil, pine oil, lavender oil and rosemary oil , could not obtain a satisfactory WSD of $460 \mu \mathrm{m}$, even for the base fuel A1 which has WSD value under the acceptable limit of $460 \mu \mathrm{m}$, except from the pine oil at the concentration level of $200 \mathrm{ppm}$ and the eucalyptus oil at the concentration level of $500 \mathrm{ppm}$.

3. Lubricating mechanisms of essential oils are probably controlled by some of the constituents present in essential oils and their polar constituent contribution but this needs further investigation.

4. Overall, it appears that the essential oils having increased density and viscosity exhibit improved lubricating performance in the range of 200-5000 ppm.

From the study on gasoline lubricity it was concluded that to a large extent, gasoline lubrication has to rely on its bulk components to provide good film forming lubricating ability, except the inherent ability of tiny polar amounts or other impurities to provide filmforming characteristics during an applicant load. Conductivity values of LRP gasolines indicate the influence of such polar compounds as potassium additives and their ability to be activated to form chemical bonds in the metal surface above $5 \mathrm{ppm}$ limit concentration.

Nineteen gasoline samples were found to be adulterated based on the quinizarin tracing and the sulphur content. Also, some of these samples were found to be mixed up with aromatic solvents. But, most of the key properties of the gasoline fuels were found to comply with the current EU legislation. The degree of adulteration does influence the lubricity especially for additized LRP gasoline samples altering the final values.

The findings of this research, verified the poorer lubricating properties of gasoline fuels compared with that of diesel fuels. Different type of gasoline fuel is affected in different degree from the compositional characteristics of the fuel and its physico-chemical properties.

Potassium concentration seems to play a significant role even in very low concentrations protecting satisfactorily from wear under boundary conditions.

The amount of water that could be absorbed during handling must be taking into account.

It is known that certain alkali compounds may accelerate the oxidation of certain organic compounds which are found in the gasoline fuels. However, further research on the oxidation stability of gasoline fuels and its effect on gasoline lubricity must be initiated in this direction.

\section{Author details}

Evripidis Lois and Panagiotis Arkoudeas

National Technical University of Athens, School of Chemical Engineering, Greece

\section{References}

[1] P. Arkoudeas, F. Zannikos, D. Karonis, E. Lois, Lubricity assessment of gasoline fuels Fuel Processing Technology (In process) 
[2] P. Arkoudeas, E. Lois, F. Zannikos (2008) The tribological behaviour of essential oils in low sulphur automotive diesel Fuel Volume 87 Issues 17-18 Pages 3648-3654

[3] G. Aanastopoulos, P. Arkoudeas, E. Lois, F. Zannikos, S. Kalligeros, P. Shoinas (2003) Study of the tribological properties of automotive diesel - effect of sulphur and nitrogen compounds $4^{\text {th }}$ Greek National Congress of Chemical Engineering in Patras

[4] Arkoudeas P., Karonis D., Lois E., Korres D., Karavalakis G., (2005) Vegetable oils, essential oils and their derivatives as substitutes and anti-wear additives of diesel engines $1^{\text {st }}$ National Greek Congress of Alternative Fuels in Athens

[5] Spikes HA, Wei DP. (2000) Fuel lubricity - fundamentals and review Fuels International 1:45-65.

[6] Hadley JW, Owen GC, Mills B. (1993) Evaluation of high frequency reciprocating wear test for measuring diesel fuel lubricity SAE paper 932692.

[7] Wei D., (2000) Thirty years of research on fuel lubricity Shigou Xuebao Shigou Jiagong.

[8] Miura M, Ikeda T, Takizawa H, Yoshida H, Ikebe H. (1997) Study on lubricity of low sulfur diesel fuels SAE Paper 972895.

[9] Lacey PI, Lestz SJ. (1992) Effect of low lubricity fuels on diesel injection pumps-Part I: field performance SAE Paper 920823.

[10] Lacey PI, Lestz SJ. (1992) Effect of low lubricity fuels on diesel injection pumps - Part II: laboratory evaluation SAE Paper 920824.

[11] Barbour RH, Rickeard DJ, Elliott NG. (2000) Understanding diesel lubricity SAE Paper 2000-01-1918.

[12] Wei DP. (1986) The lubricity of fuels I. Wear studies on diesel fuel components Acta Petrolei Sinica 2:79-87.

[13] Wei DP. (1990) The lubricity of fuels II. Wear studies using model compounds Acta Petrolei Sinica 4:90-95.

[14] Wei DP. (1990) The lubricity of fuels. III. Wear studies on diesel fuels Acta Petrolei Sinica 6:15-19.

[15] Tucker RF, Stradling RJ, Wolveridge PE, Rivers KJ, Unbbens A. (1994) The lubricity of deeply hydrogenated diesel fuels - the Swedish experience SAE Paper 942016.

[16] Anastopoulos G, Lois E, Karonis D, Zanikos F, Stournas S, Kalligeros S. (2001) A preliminary evaluation of esters of mono-carboxylic acids on the lubrication properties of low sulfur diesel fuels Ind Engng Chem Res 40:452-6.

[17] CEC F-06-A-96. Measurement of diesel fuel lubricity-approved test method. HFRR Fuel Lubricity Test.

[18] Wei D-P, Spikes H.A. (2000) Fuel Lubricity - Fundamentals and Review, Fuels International p-45-65.

[19] P.I. Lacey, R.L. Mason. (2000) Fuel Lubricity: Statistical Analysis of Literature Data SAE paper 2000-01-1917.

[20] Miura M, Ikeda T, Takizawa H, Yoshida H, Ikebe H. (1997) Study on lubricity of low sulfur diesel fuels SAE Paper 972895.

[21] Cameron F. (1998) Lubricity of California diesel fuel SAE Paper 981362.

[22] Nikanjam M. (1993) Development of the first CARB certified California alternative diesel fuel SAE Paper 930728. 
[23] Wei DP. (1986) The lubricity of fuels I. Wear studies on diesel fuel components Acta Petrolei Sinica 2:79-87.

[24] Wei DP. (1990) The lubricity of fuels II. Wear studies using model compounds Acta Petrolei Sinica 4:90-95.

[25] Wei DP. (1990) The lubricity of fuels III. Wear studies on diesel fuels Acta Petrolei Sinica 6:15-19.

[26] Tucker RF, Stradling RJ, Wolveridge PE, Rivers KJ, Unbbens A. (1994) The lubricity of deeply hydrogenated diesel fuels - the Swedish experience SAE Paper 942016.

[27] Caprotti R, Bovington C, Fowler WJ, Taylor MG. (1992) Additive technology as a way to improve diesel fuel quality SAE Paper 922183.

[28] Batt RJ, McMillan JA, Bradbury IP. (1996) Lubricity additives performance and no harm effects in low sulfur fuels SAE Paper 961943.

[29] Nikanjam M., Burk E. (1994) Diesel fuel lubricity additive study SAE Paper 942014.

[30] EN 590 (2003) Automotive fuels-Diesel-Requirements and test methods.

[31] Galbraith RM, Hertz PB (1997) The Bocle test for diesel and biodiesel fuel lubricity SAE Paper 972862.

[32] Hertz PB. (1995) Winter engine wear comparisons with a canola biodiesel fuel blend Saskatchewan Canola Commission Report.

[33] Anastopoulos G, Lois E, Serdari A, Zanikos F, Stournas S, Kalligeros S.(2001) Lubrication properties of low-sulfur diesel fuels in the presence of specific types of fatty acid derivatives Energy Fuels 15:106-12.

[34] Anastopoulos G, Lois E, Karonis D, Zanikos F, Stournas S, Kalligeros S. (2001) A preliminary evaluation of esters of mono-carboxylic acids on the lubrication properties of low sulfur diesel fuels Ind Engng Chem Res 40:452-6.

[35] Wei D, Spikes H. (1986) The lubricity of diesel fuels. Wear 111:217- 35.

[36] Wanda Sellar. (2001) The Directory of Essential Oils Reprint, Essex: The C.W. Daniel Company, Ltd.

[37] Tsurutani K, Takei Y, Fujimoto Y, Matsudaira J, Kumamoto M. (1995) The effects of fuel properties and oxygenates on diesel exhaust emissions SAE Paper 952349.

[38] Akasaka Y, Sukurai Y. (1994) Effects of oxygenated fuel and Cetane improver on exhaust emissions from heavy-duty DI diesel engines SAE Paper 942023.

[39] Bruce A. Buchholz, Charles J. Mueller, Glen C. Martin, A. S. Cheng, Robert W. Dibble and Brian R. Frantz. (2004) Tracing fuel component carbon in the emissions from diesel engines Nuclear Instruments and Methods in Physics Research Section B: Beam Interactions with Materials and Atoms 223-224:837-841

[40] Catalog handbook of fine chemicals (2005-2006) Aldrich Chemical Company, Inc.

[41] Vogel's textbook of practical organic chemistry (1989) 5th ed. Bath Press.

[42] Wanda Sellar, (2001) The Directory of Essential Oils Reprint, Essex: The C.W. Daniel Company Ltd.

[43] A.J. Von Wielligh, N.D.L. Burger, T.L. Wilcocks (2003) Diesel Engine Failures due to Combustion Disturbances, caused by Fuel with Insufficient Lubricity Industrial Lubrication and Tribology Vol. 55, p-65-75. 